\title{
Scale and Sensitivity of Songbird Occurrence to Landscape Structure in a Harvested Boreal Forest
}

\section{Échelle et sensibilité de la fréquence d'occurrence des oiseaux chanteurs à la structure du paysage dans une forêt boréale sous exploitation forestière}

\author{
$\underline{\text { Philip D. Taylor }}^{1}$ and Meg A. Krawchuk ${ }^{2}$
}

\begin{abstract}
To explore the spatial scales at which boreal forest birds respond to landscape structure and how those responses are influenced by forest harvest, we quantified the relationship between amounts of forest in the landscape at multiple spatial scales and the occurrence of 11 common boreal songbirds in western Newfoundland. The habitat type was assessed at a local scale ( $25 \mathrm{~m}$ diameter area) and amounts of forest habitat were measured at neighborhood $(300 \mathrm{~m})$ and landscape $(2500 \mathrm{~m})$ scales. We further compared how these relationships differed, depending on whether the landscape had been harvested or not, i.e., the landscape context. Landscape-scale metrics were related to occurrence for 7 of 11 species. For five of these seven, landscape context was also important. Landscape context was not important in models that did not contain a landscape-scale term. In four of five of the models including landscape context, there was an interaction of the term with either landscape or neighborhood effects, indicating that, not only was there an effect of forest harvest at the broad scale, but that effect altered the response of the species to other metrics. For the majority of species, overall occurrence tended to be higher in natural than in harvested landscapes, especially at higher levels of forest cover. Interestingly, for some species, occurrence was relatively similar across levels of forest cover within harvested, but not natural, landscapes. The results suggest some scale-invariance in species' responses to landscape structure, and that some species respond to landscape structure at scales that are broader than those implied by our current knowledge of territorial or dispersal distances. Collectively, the results also suggest that forest management needs to consider not only how local-scale processes might be influenced by local-scale changes in amounts of forest, but also how the broader scale context might interact with those local-scale changes to produce counter-intuitive results. The complex nature of some of the relationships we observed suggests that generalized management policy for forests and songbirds will be elusive.
\end{abstract}

RÉSUMÉ. Afin d'étudier les échelles spatiales associées à la réponse des oiseaux de la forêt boréale à la structure du paysage et l'influence de l'exploitation forestière sur ces réponses, nous avons quantifié la relation entre le couvert forestier à plusieurs échelles spatiales et la fréquence d'occurrence de 11 espèces communes d'oiseaux chanteurs de l'ouest de Terre-Neuve. Le type d'habitat a été caractérisé à l'échelle locale (rayon de 12,5 m) et les superficies d'habitat forestier ont été mesurées à l'échelle du voisinage $(\mathrm{r}=150 \mathrm{~m})$ et du paysage $(\mathrm{r}=1250 \mathrm{~m})$. De plus, nous avons déterminé si ces relations variaient selon que le paysage avait subi la coupe ou non, c.-à-d. en fonction du contexte du paysage. Les paramètres du paysage étaient reliés à la fréquence de 7 des 11 espèces. Pour cinq de ces sept espèces, le contexte du paysage était aussi important. Le contexte du paysage n'était pas important dans les modèles qui ne comprenaient pas de terme mesuré à l'échelle du paysage. Dans quatre des cinq modèles incluant le contexte du paysage, il

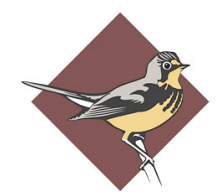

BIRD STUDIES CANADA 
y avait une interaction avec le paysage ou le voisinage, ce qui indique qu'il y avait non seulement un effet à grande échelle de l'exploitation forestière, mais aussi que cet effet modifiait la réponse des espèces aux autres paramètres. Pour la majorité des espèces, la fréquence tendait à être plus élevée dans les paysages naturels que dans les paysages sous exploitation forestière, particulièrement lorsque le couvert forestier était relativement élevé. Fait intéressant, pour certaines espèces, la fréquence était relativement semblable à tous les niveaux de couvert forestier des paysages sous exploitation, mais non dans les paysages naturels. Les résultats suggèrent que la réponse de certaines espèces à la structure du paysage est indépendante de l'échelle, et que certaines espèces répondent à la structure du paysage à des échelles plus vastes que celles suggérées par nos connaissances actuelles sur la dimension des territoires et la dispersion. Dans leur ensemble, les résultats suggèrent aussi que l'aménagement forestier devrait non seulement considérer la façon dont les processus à l'échelle locale peuvent être influencés par des changements de la quantité de forêt à cette même échelle, mais aussi comment le contexte à une échelle plus vaste pourrait interagir avec les changements locaux pour produire des résultats surprenants. La nature complexe de certaines des relations observées suggère que la généralisation de règles d'aménagement des forêts et de leur avifaune demeure peu probable.

Key Words: boreal; conservation; distribution; generalized linear mixed-effects models; landscape context; songbirds

\section{INTRODUCTION}

Songbird distributions are influenced by a suite of natural and anthropogenic factors across a range of scales. Detailed habitat studies continue to improve our understanding of local-scale songbird ecology (Marshall and Cooper 2004) and recent attention given to assessing the influence of broad-scale structure in avian ecology has been rewarding (Mazerolle and Villard 1999, Norton et al. 2000, Heikkinen et al. 2004, Betts et al. in press). Empirical and theoretical studies have shown that the amount and configuration of habitat as well as the matrix between suitable local habitat patches influence habitat use and population persistence of many organisms at a landscape scale (Trzcinski et al. 1999, Villard et al. 1999, Fahrig 2001, Ricketts 2001). The ecological processes responsible for these relationships can lead to effects that vary and/ or interact among scales of study (Krawchuk and Taylor 2003).

Movement behavior is one process that can be used to assess biologically relevant domains of spatial scale within a study system (Krawchuk and Taylor 2003). For a forest songbird, both foraging and territory defence during the breeding season (e.g., Drolet et al. 1999, Lambert and Hannon 2000, Norris and Stutchbury 2001, Flather and Bevers 2002) affect territory size, which represents the "immediate" resources required by an individual.
The territory exists within a broader landscape offering the potential for interaction between an individual, its environment, interspecifics, and conspecifics during the breeding season. For songbirds, a breeding territory is embedded in a much larger home range used for regular foraging or extra-pair copulation (e.g., Norris and Stutchbury 2001). Hence, it is also logical that landscape structure may influence territory selection by altering the ability of individuals to access resources (e.g., landscape connectivity; Taylor et al. 1993, Bélisle 2005) and enhancing or inhibiting interaction among conspecifics within the population, supplementing and/or complementing (Dunning et al. 1992, Taylor et al. 1993, Norton et al. 2000) suitable areas of habitat for both adults and juveniles (Vega Rivera et al. 1998). Consequently, changes to such measures as the amount of forest in the landscape through natural or anthropogenic disturbance have the potential to modify songbird behavior in different ways at different spatial scales. This has implications for ecological surveys and management.

Boreal landscapes vary in structure, species composition, and natural disturbance regime across Canada and Alaska, USA (Rowe 1972, McCarthy 2001, Stocks et al. 2002). The dominance of gap dynamics and old, complex age structures in some boreal forests are now being documented (Cumming et al. 2000, McCarthy 2001). In parts of eastern Canada, small-scale disturbances drive 
boreal forest dynamics because of low fire frequency and/or minimal insect outbreak, resulting in multi-cohort, self-perpetuating, and gap-driven forests (McCarthy 2001, Thompson et al. 2003, Pham et al. 2004). Communities of songbirds in these old-growth boreal forests may be sensitive to both local- and broad-scale changes in landscape structure resulting from clear-cut forest harvesting because the scale of this management practice differs considerably from the natural disturbance regime of the region.

There has been limited use of appropriate methods to quantify ecological relationships occurring across multiple spatial scales (e.g., Miller et al. 2004). Intuitively, simultaneous estimation of these relationships promises a more parsimonious assessment of the system than post hoc comparison of independent estimates at different scales. Ecologists are now able to carry out more elegant and unified analyses of multi-scaled data because of recent developments in generalized mixedeffects regression models (Pinheiro and Bates 2000, Skrondal and Rabe-Hesketh 2004). These methods have the potential to provide a quantitative ecological basis for management decisions and conservation targets.

Our purpose was to assess whether relationships between songbird incidence and the amount of forest in the landscape varied with scale and context. To achieve this, we quantified and compared the effects of the amount of forest on the occurrence of 11 species of songbirds at multiple scales under two disturbance regimes (natural and harvest) in the eastern boreal forest on the island of Newfoundland, Canada. We first determined how the relationship between the amount of forest in a landscape and songbird incidence differed between spatial scales associated with immediate (i.e., territorial) and broader landscape-scale (i.e., extra-territorial) habitat use. We then assessed how that relationship differed depending on whether the amount of forest in the landscape was a function of forest harvesting or was a natural phenomenon. We used generalized linear mixed-effects regression models to estimate these relationships simultaneously. The resulting models provide a suite of functionally relevant spatial scales for each species that are being used to help design further studies of avian demography in the region and by forest managers as a means to develop scenarios of the impacts of future harvesting on songbird distributions.

\section{METHODS}

\section{Field sampling: Survey landscapes}

The Greater Gros Morne Ecosystem (GGME) in western Newfoundland, Canada, is a boreal forest region with a mosaic of mature forest, scrub, peatland bogs, and ponds, resulting in natural heterogeneity characterized by patches and openings (the Corner Brook boreal forest region within the Boreal Shield Eco-zone region B28.b, Rowe 1972). The standing forest is homogeneous and composed primarily of balsam fir Abies balsamea, a late-successional nonpyrogenic species, and black spruce Picea mariana. Areas of old-growth gap-replacing boreal forest (McCarthy 2004) that had not been harvested prior to the early 1990s (Corner Brook Pulp and Paper Ltd., personal communication) are found in the north and west, including Gros Morne National Park, whereas areas harvested for pulp and timber are situated in the south and east. The southern portion of the GGME is composed of young forest at various stages of regeneration, as well as mature second growth. At the time of this study, mechanized clear-cutting was the only method of harvest. De-limbing occurred on site, leaving abundant slash; a low density of hardwood, primarily paper birch Betula papyrifera, was left as isolated standing trees after harvest. Forest fires, blow downs, and insect outbreaks are uncommon in this moist, cool region (Sturtevant et al. 1996, McCarthy 2001). Thompson et al. (1999, 2003), Setterington et al. (2000), and McCarthy (2004) provide a thorough description of the forest region and age of the study site and vicinity.

Survey landscapes were situated in a $30 \times 40-\mathrm{km}$ (12,000-ha) area of the GGME, including Gros Morne National Park and the Main River watershed. During 1998 and 1999, we established survey transects in 15 unharvested (natural) landscapes in the region. Each landscape was delineated as a 1250 $\mathrm{m}$ radius area and was surveyed using two perpendicular 2500-m transects. One transect ran north-south, and the other, east-west; the overlapping mid-point was the center. Each transect arm consisted of 10 sampling points $\sim 250 \mathrm{~m}$ apart, for a total of 21 survey points in each landscape. Nine of fifteen landscapes were surveyed in 1998 and 14 of 15 in 1999. Weather and logistical constraints resulted in incomplete replication 
among years. In 2000, 65 new survey landscapes were initiated, encompassing areas of natural and harvested forest. The time of harvest ranged from 1990 to 2000; thus, harvested landscapes were at various stages of early regeneration. Regeneration in the area proceeds very slowly; the maximum height of trees in 10-yr-old cuts was generally $<1$ $\mathrm{m}$, so cuts remained highly distinctive from other habitat types. Cut areas were irregularly shaped because of the terrain and ranged in size from approximately 1 to $4 \mathrm{~km}^{2}$. During 2000, landscapes were surveyed using a modified transect method. Two transects forming a V-shape were used, consisting of a total of 12 survey points at $\sim 250-\mathrm{m}$ intervals. The change in transect shape (1998 and 1999 versus 2000) was implemented to increase the spatial scale of our survey effort. The change in transect shape decreased the number of survey points within each landscape from 21 to 12 , but maintained the hierarchical structure. In total, 8 of 88 landscapes were visited more than once over 3 yr of surveys. Every survey point was georeferenced using a Trimble GeoExplorer Global Positioning System (GPS; Trimble, Sunnyvale, CA) with differential correction.

\section{Data collection}

Each landscape was surveyed once during a given breeding season to identify species' general habitat associations. The entire survey landscape was sampled on a single day and one observer surveyed all points along a given transect. We elected to survey points only once because our intent was to measure use and distribution during the breeding season (i.e., we did not intend to measure breeding activity). This allowed us to sample extensively at a broad landscape scale, which was the primary scale of interest. The order in which landscapes were surveyed was randomized as much as possible to reduce confounding effects of landscape structure, location, weather, and date. Bird surveys were completed on mornings with low wind and precipitation and consisted of 10 -min point counts following general standards described in Ralph et al. (1993). Unlimited distance counts were used to determine species occurrence. Surveys began at sunrise and were completed by $0930 \mathrm{~h}$.

The amount of forest around each survey point was measured using a three-tiered spatial hierarchy that included local, neighborhood, and landscape scales. Local and neighborhood scales represented the general size of a songbird territory (e.g., Drolet et al. 1999, Lambert and Hannon 2000, Norris and Stutchbury 2001, Flather and Bevers 2002) and were interpreted together because local data were collected within a $12.5-\mathrm{m}$ radius of each survey point, but birds were surveyed and used areas well beyond that distance. The local scale simply provided additional general structural information relevant to each survey point. The landscape scale was selected to encompass territories of multiple individuals to represent a scale of interaction between an individual, the environment, and conspecifics during the breeding season.

At the local scale (LOCAL), we obtained a simple categorical measure of habitat, defined as the major resource type within approximately a $12.5-\mathrm{m}$ radius of each survey point. This was assessed in the field using a subjective classification of seven resource types: forest (all age classes of mature forest), scrub, bog, barren, tuckamore, recently cut, and early regeneration forest. Tuckamore is a small, stunted evergreen tree with gnarled, spreading roots, found in harsh/windy areas of Newfoundland. Recently cut and regeneration forest categories were only appropriate in 2000 . Recently cut was defined as harvested forest with saplings measuring $<1.5 \mathrm{~m}$ tall ( <4 yr since harvest; 1996-2000), and early regeneration forest as harvested forest with saplings $>1.5 \mathrm{~m}$ tall ( $\sim 4$ yr since harvest; 1990-1995). We measured and included LOCAL effects in models as a mechanism to account for variance that is a direct function of the area around a sampling point. Although we recognize that individuals were frequently detected $>25 \mathrm{~m}$ from a survey point, variance in habitat preferences and differences in detectability between habitats can be accounted for by including these local effects. Further, they allow for a more conservative assessment of the broader scale terms.

The amount of forest at the neighborhood and landscape scales was measured using GIS analysis (SPANS, TYDAC Research Inc., Nepean, Ontario, Canada) of maps delineating land-cover types interpreted from 1:12,500 scale aerial photographs of the GGME taken between 1985 (areas with no harvesting) and 2000 (areas of ongoing harvest). Photographs had been previously interpreted for forest classification according to the Gros Morne Photographic Interpretation Procedures and Technical Specifications by Torngat Consultants. Full meta-data are available from Gros Morne National Park. 
The neighborhood and landscape metrics described the amount of vertical structure at each survey point. Cover type was aggregated into two categories, woodland (forest and scrub) and open (bog, barren, water, and harvested forest). Forest was chosen as a generic cover type for this aggregation because of the dominance of balsam fir throughout the GGME, although site quality differed in association with soil productivity (Thompson et al. 1999, Corner Brook Pulp and Paper Ltd., personal communication). The majority of the standing forest was classified as 4180 yr or $>80$ yr old (500-yr-old balsam fir have been documented in the region; McCarthy [2001]) and measured 3.5-6 $\mathrm{m}$ in height. Forest stands were those with $>25 \%$ of the ground area covered by tree crown. Land supporting softwood scrub growth between 1 and $3.5 \mathrm{~m}$ in height and $>10 \%$ crown coverage was classified as scrub. In visual interpretation of aerial photos, forest may be distinguished from scrub; at the extremes, their physical structure differs, but the two classes exist along a gradient, so we thought that splitting them would be ad hoc and subjective. We therefore merged the categories as "woodland cover", which is appropriate for the questions addressed by this research.

At the neighborhood scale, woodland cover (N_WOOD in statistical models; Fig. 1) was calculated as the proportion of forest and scrub within a $150-\mathrm{m}$ radius of the survey point (within a 7-ha neighborhood). Landscape-scale woodland cover (L_WOOD in statistical models; Fig. 1) was derived similarly to that at the neighborhood scale, using proportions of forest and scrub within a 1250$\mathrm{m}$ radius of each survey point (within a 484-ha landscape). Each landscape was categorized as unharvested if $<5 \%$ of the area within it was harvested; otherwise, it was considered harvested (CONTEXT in statistical models; Fig. 1).

\section{Data analysis: Avian distribution in relation to amount of forest}

We examined the relationship between the amount of forest and bird incidence for the 11 most abundant bird species in the region (Table 1) at the three spatial scales using a maximum likelihood approach for generalized linear mixed-effects regression with a logistic link (glmmML [Broström 2003]; R statistical package, The R Development Core Team version 2.0). Mixed-effects models include both fixed and random effects in the estimation of model parameters, and can be used to describe relationships between a response variable and covariates in data that are nested within different spatial scales (Pinheiro and Bates 2000). This modeling approach was appropriate because multiple points were surveyed within each landscape; failing to account for this structure would result in a lack of independence among points.

We included the random effect R_LANDSCAPE in each model to group survey-point data from each landscape. This random effect would also account for unmeasured variation among landscapes attributable to the combined influences of survey date (e.g., weather, progression through the breeding season), observer, and location. Terms assessed as fixed effects included: LOCAL, N_WOOD, L_WOOD, CONTEXT, and the interaction effects N_WOOD $\times$ CONTEXT, and L_WOOD $\times$ CONTEXT. Treatment contrasts were applied to LOCAL using the forest category as the reference level. A quadratic term of L WOOD was included to determine if any non-linear (e.g., threshold-type) patterns were suggested by the data. A difference between CONTEXT levels would represent a change in the odds of detecting each species between harvested and unharvested landscapes while accounting for variation with local, neighborhood, and landscape terms. Interaction terms were used to describe changes in the influence of the amount of forest between harvested and unharvested landscapes. CONTEXT had no contrast among years because harvested landscapes were only surveyed in 2000. Survey YEAR (1998, 1999, or 2000) was included as a proxy for a variety of annual effects such as annual weather or regional patterns.

Data from all $3 \mathrm{yr}$ of survey effort were pooled in our analyses. Data collected from the same points in different years were inherently correlated (repeated measurements); however, only 8 of 88 landscapes were sampled repeatedly, so we did not group the data to explicitly account for this correlation. Occurrence (detection of a given species at a survey point) was chosen over abundance as the response variable because we wanted to focus on species' associations with woodland cover and disturbance, rather than the relative quality or carrying capacity of landscapes. The observed sampling distribution of neighborhood and landscape structure represented by woodland cover terms (N_WOOD and L_WOOD) differed 
Fig. 1. The frequency distribution of neighborhood woodland cover (N_WOOD) and landscape woodland cover (L_WOOD) in harvested (CUT) and unharvested (NAT) contexts.
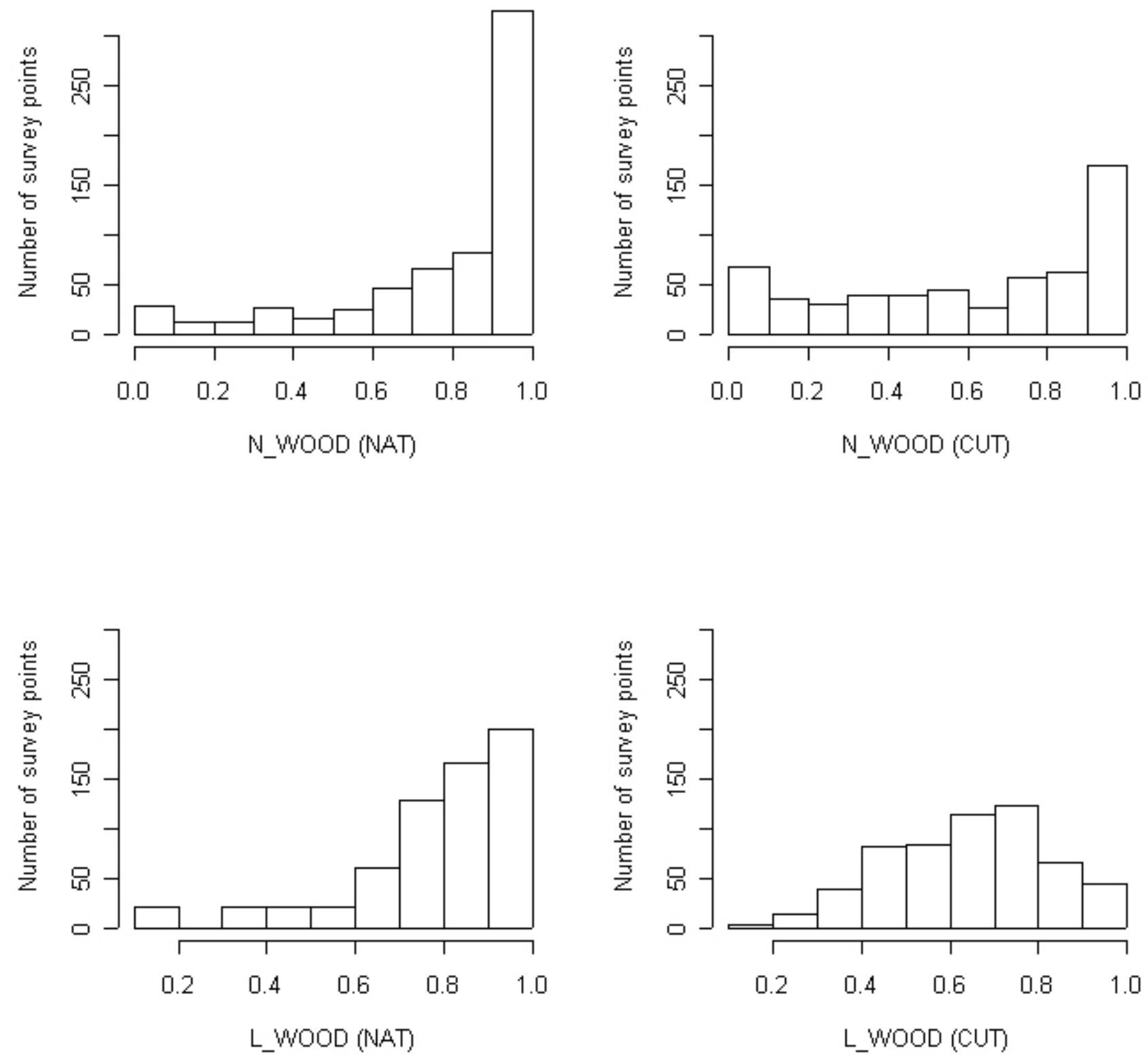
Table 1. Summary of species occurrence and general habitat associations (literature derived) in western Newfoundland, 1998-2000 ( $\mathrm{n}=1214$ point counts).

\begin{tabular}{|c|c|c|c|c|c|c|}
\hline \multirow[t]{2}{*}{ Species code } & \multirow[t]{2}{*}{ Common name } & \multicolumn{4}{|c|}{ Occurrence } & \multirow[t]{2}{*}{ Habitat association } \\
\hline & & $\mathrm{n}$ & cut & uncut & overall & \\
\hline AMRO & American Robin & 414 & 0.36 & 0.32 & 0.34 & Open/Edge \\
\hline BLPW & Blackpoll Warbler & 605 & 0.49 & 0.51 & 0.50 & Woodland \\
\hline DEJU & Dark-eyed Junco & 433 & 0.38 & 0.34 & 0.36 & Edge \\
\hline FOSP & Fox Sparrow & 437 & 0.37 & 0.35 & 0.36 & Edge \\
\hline HETH & Hermit Thrush & 448 & 0.40 & 0.34 & 0.37 & Woodland \\
\hline LISP & Lincoln's Sparrow & 338 & 0.26 & 0.30 & 0.28 & Open/Edge \\
\hline NOWA & Northern Waterthrush & 386 & 0.30 & 0.34 & 0.32 & Woodland \\
\hline RCKI & Ruby-crowned Kinglet & 689 & 0.48 & 0.65 & 0.57 & Woodland \\
\hline SWTH & Swainson's Thrush & 122 & 0.10 & 0.10 & 0.10 & Woodland \\
\hline WTSP & White-throated Sparrow & 962 & 0.83 & 0.76 & 0.79 & Open/Edge \\
\hline YBFL & Yellow-bellied Flycatcher & 529 & 0.49 & 0.38 & 0.44 & Woodland \\
\hline YRWA & Yellow-rumped Warbler & 783 & 0.61 & 0.68 & 0.64 & Woodland/Edge \\
\hline
\end{tabular}

among harvested and unharvested landscapes (CONTEXT; Fig. 1); however, the range of each distribution remained constant. This consistency enabled the comparison of distribution patterns between disturbance types.

We used Akaike's Information Criterion (AIC) to select models of the data for each species. Vaida and Blanchard (2005) illustrate the appropriateness of AIC for this type of study. We compared global models (i.e., including all a priori selected candidate variables) to all possible candidate sub-models to assess which described the observations of each species distribution most parsimoniously (Burnham and Anderson 2002). The candidate model having the lowest AIC was considered the best model. The following criteria for the change in AIC were used: a difference in AIC of $\leq 3$ suggested no model improvement, a reduction of $>3-7$ suggested the term of interest improved the model, and a reduction of $\geq 10$ indicated that a model explained substantially more structural variation in the data relative to the alternative (Burnham and Anderson
2002). We used AIC as an objective means of determining whether neighborhood or landscape woodland cover better described variation in species distributions. It enabled us to differentiate between alternative hypotheses describing the most relevant spatial scales of response to woodland cover and context. The Wald test-statistic was used to support the AIC selection of each term using a critical $P$ value of 0.05 . Parameter estimates were compared across all models to assess the stability of the coefficients to the inclusion of other explanatory variables.

True measures of a model's overall goodness of fit are difficult to formulate for mixed models and the area is an active one for statistical research. HosmerLemeshow tests are considered inappropriate for mixed models and Pearson $\chi^{2}$ goodness-of-fit and deviances are inappropriate for ungrouped binary data (Collett 1991, Hosmer and Lemeshow 2000), so we elected to assess the relative goodness of fit via AIC. Further, the prospective study design also permitted the use of the Receiver Operating 
Characteristic (ROC), which can be used to describe the ability of a given model to discriminate the presence or absence of an incident in reference to the observed distribution. An ROC of 0.5 suggests that we would have as much predictive power by flipping a coin; values of 0.6-0.7 suggest moderate discrimination; values of $0.7-0.8$ suggest acceptable discrimination; and values of $0.8-0.9$ suggest excellent discrimination (Hosmer and Lemeshow 2000). Although we were not specifically interested in prediction within this study, the ROC values give some additional insight into the potential generality of the different models.

For all models, we conducted an analysis of residuals to examine outliers and spatial autocorrelation.

\section{RESULTS}

Bird surveys were conducted from 2 June to 1 July 1998, 9 June to 3 July 1999, and 11 June to 14 July 2000. The area is at a relatively high elevation and these dates fall within the normal breeding season for most species. In total, 66 species of birds were detected. Forty species of birds were recorded in 1998 and again in 1999, although assemblage composition varied between years. In 2000, 63 species were detected and the increase reflected increased survey effort in both natural and harvested landscapes. The same 11 species were most abundant in all $3 \mathrm{yr}$ and included Yellow-bellied Flycatcher (Empidonax flaviventris), Rubycrowned Kinglet (Regulus calendula), Hermit Thrush (Catharus guttatus), American Robin (Turdus migratorius), Yellow-rumped Warbler (Dendroica coronata), Blackpoll Warbler (Dendroica striata), Northern Waterthrush (Seiurus noveboracensis), Dark-eyed Junco (Junco hyemalis), White-throated Sparrow (Zonotrichia albicollis), Fox Sparrow (Passerella iliaca), and Lincoln's Sparrow (Melospiza lincolnii; Table 1). Species were categorized by general habitat preference based on existing natural history information (Whittaker and Montevecchi 1997) to aid in interpreting our structural metrics (Table 1).

Landscape-scale metrics (L_WOOD or L_WOOD ${ }^{2}$ ) were included in the best models for 7 of 11 species; in five of these, the forest harvest term CONTEXT was also present (Tables 2 and 3). CONTEXT was not important in models that did not contain a landscape-scale term. In four of five of those models including CONTEXT, there was an interaction with either landscape or neighborhood effects. Whereas the positive CONTEXT effect showed a higher probability of occurrence in harvested landscapes at the $x$-intercept (low amounts of woodland cover) for the majority of these species, overall occurrence tended to be higher in natural landscapes than in harvested landscapes, especially at higher levels of forest cover (e.g., Ruby-crowned Kinglet, Hermit Thrush, Lincoln's Sparrow, Blackpoll Warbler, and Fox Sparrow; Fig. 2). This trend was supported for all three significant landscape interaction terms that showed a lower occurrence in harvested landscapes (Table 2). Interestingly, for some species, occurrence was relatively similar across levels of forest cover within harvested, but not natural, landscapes (e.g., Ruby-crowned Kinglet, Darkeyed Junco, Northern Waterthrush, and Hermit Thrush).

Local or neighborhood metrics were present in the best models for eight species, three of which did not contain any landscape-level effects (Tables 2 and $3)$. In only three models were there both landscapeand neighborhood-scale effects. In two of these, there were comparable patterns of incidence across both metrics. Plots of N_WOOD versus proportional occurrence (not presented here; similar to Fig. 2) showed similar relationships between incidence of N_WOOD and L_WOOD for most species. For one species (Yellow-bellied Flycatcher) there were no terms associated with the amount of forest included in the best model. The incidence of four species varied among years (Tables 2 and 3 ).

ROC values (measuring overall fit) ranged from 0.5 to 0.8 ; seven species (Ruby-crowned Kinglet, Blackpoll Warbler, Northern Waterthrush, Darkeyed Junco, White-throated Sparrow, Fox Sparrow, and Lincoln's Sparrow) had acceptable predictive power (i.e., >0.6; Table 2).

\section{DISCUSSION}

We show that for most of the suite of abundant species of boreal songbirds in a region of western Newfoundland, occurrence is related to the amount of woodland cover at either within-neighborhood or landscape scales. As expected, for the majority of species ( 8 of 11), there was a relationship between occurrence and metrics at local or neighborhood scales. This is a simple function of the immediate, within-territory habitat needs of most species. A 
Table 2. Summary of model outcomes illustrating the general relationship between occurrence and significant explanatory variables. Parameter estimates and standard errors are presented in Table 3. :, interaction; ${ }^{2}$, quadratic; CUT, harvested context; NAT, natural context.

\begin{tabular}{|c|c|c|c|c|c|c|c|}
\hline Species & Global AIC & Best AIC & ROC & Within-neighborhood & Landscape & Context & Year \\
\hline AMRO & 1487 & 1481 & 0.6 & LOCAL - N_WOOD & & & \\
\hline LISP & 1151 & 1146 & 0.8 & LOCAL - N_WOOD & & & $1998=1999>2000$ \\
\hline YRWA & 1511 & 1502 & 0.6 & + N_WOOD & & & \\
\hline FOSP & 1333 & 1331 & 0.7 & LOCAL & - L_WOOD & & \\
\hline WTSP & 1032 & 1028 & 0.8 & LOCAL & - L_WOOD & & $1999=1998>2000$ \\
\hline BLPW & 1373 & 1368 & 0.7 & LOCAL + N_WOOD & $\begin{array}{l}+ \text { L_WOOD } \\
- \text { L_WOOD }^{2}\end{array}$ & - CUT & \\
\hline RCKI & 1380 & 1376 & 0.7 & LOCAL + N_WOOD & $\begin{array}{l}\text {-L_WOOD:CUT } \\
+ \text { +L_WOOD:NAT }\end{array}$ & + CUT & $1999>1998>2000$ \\
\hline DEJU & 1465 & 1466 & 0.7 & $\begin{array}{l}\text { LOCAL - N_WOOD:CUT } \\
+ \text { N_WOOD:NAT }\end{array}$ & + L_WOOD & $+\mathrm{CUT}$ & \\
\hline NOWA & 1381 & 1377 & 0.7 & & $\begin{array}{l}\text {-L_WOOD:CUT } \\
+ \text { +L_WOOD:NAT }\end{array}$ & + CUT & $1998=1999>2000$ \\
\hline HETH & 1489 & 1479 & 0.5 & & $\begin{array}{l}\text {-L_WOOD:CUT } \\
+ \text { +L_WOOD:NAT }\end{array}$ & $+\mathrm{CUT}$ & \\
\hline YBFL & 1519 & 1507 & 0.6 & & & & $2000>1999=1998$ \\
\hline
\end{tabular}

landscape-scale term was important for 7 of 11 species, suggesting that for many species, processes acting beyond the scale of the territory likely influence behavioral decisions during the breeding season. Many songbirds use habitat outside of their immediate territories (e.g., Norris and Stutchbury 2001) to secure extra-pair copulations and additional resources for young. Species responded similarly to territorial-scale metrics when compared to landscape-scale metrics, but models for only 3 of 11 species contained terms for both, suggesting that appropriate scales for the study of behavior can vary substantially among similar species and, more importantly, can be much larger than those typically explored by researchers.

Landscape context was only important for the species that also showed relationships with metrics at landscape scales. For roughly one-third of the species (4 of 11), the nature of the relationship between incidence and woodland cover depended on whether the landscape had been harvested (i.e., an interaction). For these species, the broader landscape-scale context (the matrix; Ricketts 2001) influences how a given species responds to landscape structure at the same and finer scales (Jonsen and Taylor 2000). This could be a manifestation of the influence of fragmentation on movement processes, where changes in the broader matrix between suitable landscapes alter their accessibility (changes in behavior and connectivity) or use (resource supplementation).

The results demonstrate a scale invariance in species' responses to landscape structure, although naturally, different species respond at different scales. More importantly, some species respond to landscape structure at scales that are broader than those implied by our current knowledge of territorial or dispersal distances (e.g., Bélisle et al. 2001, Krawchuk and Taylor 2003). Landscape context (Jonsen and Taylor 2000) alters even those simple 
Table 3. Parameter estimates (standard errors in parentheses) for significant variables for the best models (Table 2) to explain the occurrence of focal bird species in western Newfoundland, 1998-2000. Variables in italics are treatment levels of the LOCAL term in relation to forest. For factor terms, for brevity, only levels where the $P$-value was $\leq 0.05$ are presented.

\begin{tabular}{|c|c|c|c|c|c|}
\hline Species & Variable & Estimate & Species & Variable & Estimate \\
\hline \multirow[t]{3}{*}{ AMRO } & tuckamore & $-1.0(0.5)$ & NOWA & CONTEXT (NAT) & $-5.1(1.2)$ \\
\hline & recently cut & $0.8(0.4)$ & & 2000 & $-2.7(0.4)$ \\
\hline & N_WOOD & $-0.9(0.3)$ & & L_WOOD:NAT & $4.0(1.1)$ \\
\hline \multirow[t]{5}{*}{ LISP } & scrub & $1.1(0.2)$ & DEJU & recently cut & $1.2(0.4)$ \\
\hline & bog & $1.8(0.3)$ & & N_WOOD & $-1.7(0.5)$ \\
\hline & regenerating & $0.8(0.4)$ & & L_WOOD & $2.9(0.7)$ \\
\hline & N_WOOD & $-2.0(0.4)$ & & CONTEXT (NAT) & $-2.0(0.6)$ \\
\hline & 2000 & $1.2(0.5)$ & & N_WOOD:NAT & $2.2(0.7)$ \\
\hline YRWA & N_WOOD & $1.5(0.2)$ & YBFL & 2000 & $1.0(0.5)$ \\
\hline \multirow[t]{8}{*}{ RCKI } & tuckamore & $-1.3(0.4)$ & BLPW & scrub & $-2.4(1.2)$ \\
\hline & regenerating & $0.7(0.4)$ & & bog & $1.1(0.2)$ \\
\hline & barren & $-1.3(0.7)$ & & regenerating & $1.1(0.4)$ \\
\hline & N_WOOD & $1.5(0.4)$ & & barren & $2.7(1.1)$ \\
\hline & CONTEXT (NAT) & $-6.0(1.5)$ & & N_WOOD & $1.0(0.4)$ \\
\hline & 1999 & $1.1(0.6)$ & & L_WOOD & $8.8(3.8)$ \\
\hline & 2000 & $-2.5(0.5)$ & & L_WOOD $^{2}$ & $-10.2(3.0)$ \\
\hline & L_WOOD:NAT & $5.2(1.4)$ & & CONTEXT (NAT) & $0.7(0.3)$ \\
\hline \multirow[t]{6}{*}{ FOSP } & scrub & $0.5(0.2)$ & WTSP & scrub & $1.1(0.2)$ \\
\hline & bog & $0.4(0.2)$ & & bog & $0.9(0.3)$ \\
\hline & tuckamore & $1.1(0.4)$ & & regenerating & $2.3(0.6)$ \\
\hline & regenerating & $0.7(0.3)$ & & recently cut & $2.1(0.6)$ \\
\hline & recently cut & $0.8(0.4)$ & & L_WOOD & $-3.0(0.7)$ \\
\hline & L_WOOD & $-3.4(0.8)$ & & 2000 & $-0.9(0.4)$ \\
\hline
\end{tabular}




$\begin{array}{ccc}\text { HETH } & \text { CONTEXT (NAT) } & -6.0(1.0) \\ & \text { L_WOOD:CUT } & 1.8(0.7) \\ & \text { L_WOOD:NAT } & 5.5(1.0)\end{array}$

responses for some species, suggesting that the underlying processes, such as movement, are context-dependent. All of this underlies the point that prescriptions for forest management that have the goal of minimizing the effects of forest harvesting on songbird populations will need to consider more than metrics associated only with amounts of habitat (c.f., Fahrig 2001) to assess or predict future impacts. Given the complex nature of some of the relationships we observed, straightforward or generalized management policies or prescriptions are likely to be elusive. This elusiveness invites the concept of adaptive management ("learning by doing"; Walters 1986, 1997) as a method to provide insight to forest managers and conservation scientists.

\section{Landscape context}

Bird occurrence was lower in harvested than unharvested landscapes when there was a large amount of woodland cover. Further, the peak occurrence across all levels of woodland cover tended to be lower in harvested landscapes than in natural landscapes, even though incidence tended to be higher in harvested landscapes when landscape-scale woodland cover was low. The results suggest that forest harvesting is not initially detrimental to many species. The effects of landscape context are best exemplified by Hermit Thrush, Northern Waterthrush, and Ruby-crowned Kinglet. Each showed a decreasing or neutral relationship with landscape-scale woodland cover in harvested landscapes and an increasing relationship in unharvested landscapes, which likely indicates functional relationships associated with movement, foraging, and extra-pair copulation.

The occurrence of Dark-eyed Junco, Hermit Thrush, Northern Waterthrush, and Ruby-crowned Kinglet was lower in natural than harvested landscapes. This result was counter-intuitive because these species are forest inhabitants. However, this effect is manifested primarily at low levels of woodland cover. Given equally low amounts of woodland cover in a harvested and unharvested landscape, we suggest that these species can fulfill their resource needs in harvested landscapes, whereas in nonforest areas, bogs, and barrens, they cannot. In contrast, we detected more individuals of Blackpoll Warbler in natural landscapes, which may indicate that it is less able to use regenerating clear-cuts, despite its general preference for partially forested habitats within the region. Competition between Blackpoll Warbler and other early successional forest specialists could also contribute to this response.

\section{Thresholds}

Most of the relationships between occurrence and broad-scale forest cover were non-linear, suggesting that there may be thresholds where the functional response of a species changes relative to the environmental conditions (Guénette and Villard 2005; Betts et al. in press). As discussed above, these responses were frequently different between harvested and unharvested landscapes. Such responses also suggest that some species are able to supplement resources in naturally heterogeneous sites up to a point, after which their ability to access resources necessary for survival fails. The lack of a similar response in harvested landscapes suggests that the threshold at low levels of forest cover is buffered by the presence of regenerating forest. Harvesting will generally proceed on productive sites (i.e., those capable of supporting merchantable forest), so the resulting clear-cuts will also be more productive, especially when considering the addition of decaying organic matter remaining after harvesting. Other potential explanations, such as species packing post-harvest (Schmiegelow et al. 1997), are likely acting in concert. 
Fig. 2. Species incidence (proportion of sites occupied) by the amount of woodland in the landscape (L_WOOD in statistical models). Curves are smoothed loess regression lines (span $=0.8$ ) to show general trends in the data. Species are ordered by increasing overall incidence from the bottom left panel to the upper right panel.

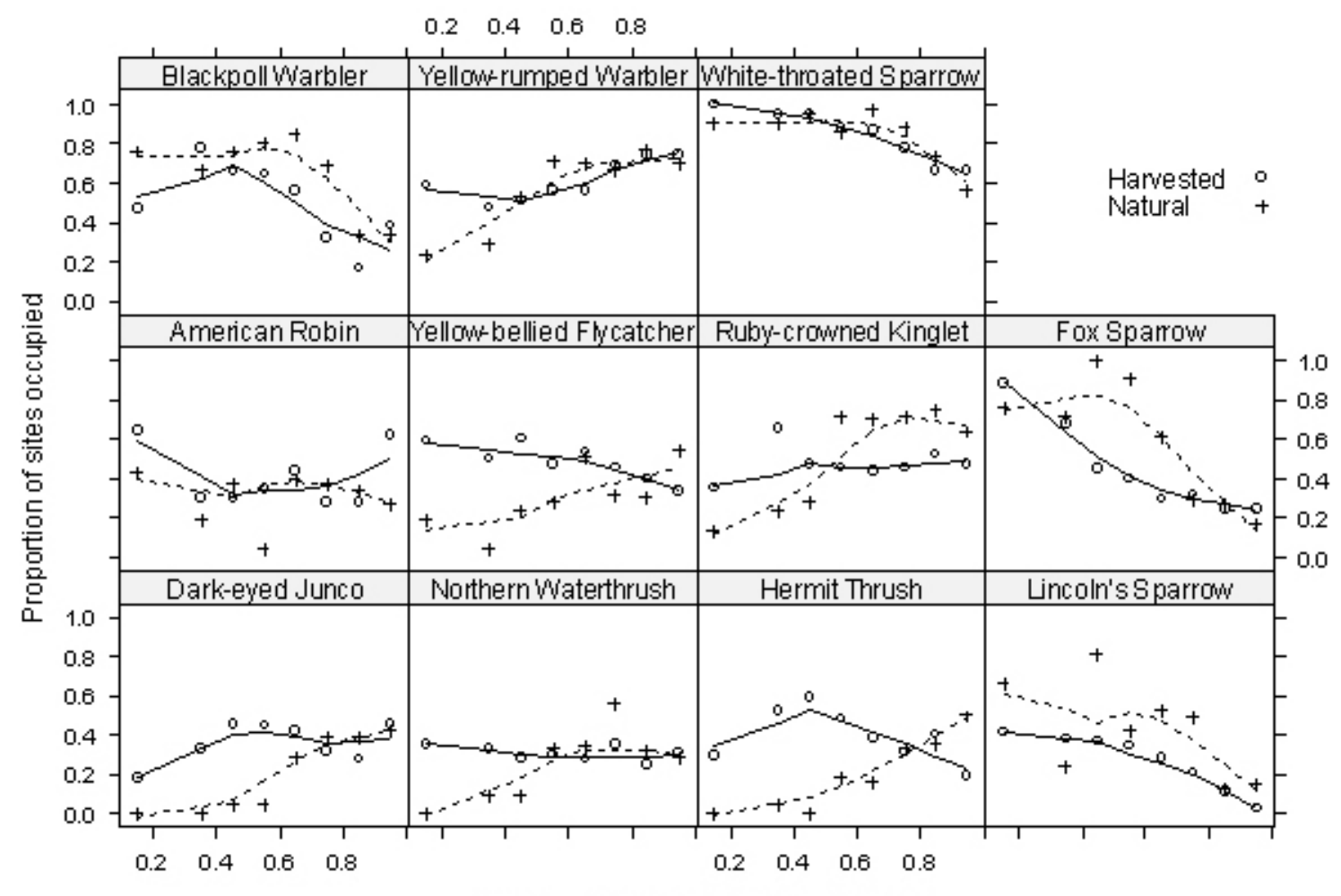

Landscape woodland cover (L_WOOD)

\section{Local and neighborhood scales and habitat associations}

The majority of species showed the same response to neighborhood metrics in harvested and natural landscapes. For all species, the local-scale effects echoed our existing understanding of their natural history in this region (Whitaker and Montevecchi 1997, Thompson et al. 1999) and elsewhere (Erskine 1977). For Dark-eyed Junco, incidence increased with neighborhood woodland cover in natural landscapes, but decreased with woodland cover in harvested landscapes. This species prefers edge and early successional habitats and this interaction may reflect its preference for harvested areas and ecotones.

We had expected that most species would respond within the neighborhood scale. However, three species were insensitive to local and/or neighborhood metrics: Hermit Thrush, Northern Waterthrush, and Yellow-bellied Flycatcher. We suggest that these species respond to the landscape structure in this region at generally broader spatial scales (e.g., see Warkentin et al. 2003), thus weakening any relationships with our local- and 
neighborhood-scale metrics. The relatively low discriminatory power of some models (e.g., American Robin, Hermit Thrush, Yellow-bellied Flycatcher) and/or the weak relationship between occurrence and our metrics (e.g., Yellow-bellied Flycatcher, Yellow-rumped Warbler) suggests that either alternative scales of structure are more important for these species or our simple metrics did not pick up appropriate resource elements. The relationship between incidence and the amount of woodland within the neighborhood scale may represent individual territory choice, even if not indicative of reproductive success (Van Horne 1983, Gunn et al. 2000, Bayne and Hobson 2001).

\section{CONCLUSIONS}

The derivation of methods to study, understand, and translate ecological patterns and processes at or to relatively large or coarse spatial scales is critical to implementing regional and national comprehensive management plans for Canada's boreal biome. Our suggestion that species within harvested landscapes can supplement resource needs by using harvested areas lends a functional hypothesis to other studies that have demonstrated the influence of broad-scale structure on boreal bird distribution and abundance in Canada (Schmiegelow et al. 1997, Drolet et al. 1999, Drapeau et al. 2000). Collectively, these studies demonstrate that landscape perspectives provide additional information on distribution patterns over patch-centered approaches (Mazerolle and Villard 1999, Norton et al. 2000), particularly in light of recent work demonstrating that there is often considerable movement outside of territorial boundaries (Norris and Stutchbury 2001). Surprisingly, however, studies that employ methods that simultaneously estimate relationships at multiple spatial scales are still rather uncommon.

We specifically emphasized the relevance of a multi-scale approach by demonstrating ecologically discriminating models of avian distribution that illustrate the concept that songbirds in this region are sensitive to the broad-scale structure of the landscape in addition to the obvious responses to local and neighborhood resources. Changes to the amount of forest in the landscape have the potential to modify songbird behavior at both local and landscape scales. For some species, those modifications to behavior may be dependent on anthropogenic processes acting at even broader spatial scales. The existence of such effects precludes the use of simple tools for management that ignore not only the multiple spatial scales of animal behavior, but also the potentially complex relationships that may change through time and cumulatively influence species persistence.

Responses to this article can be read online at: http://www.ace-eco.org/voll/iss l/art5/responses/

\section{Acknowledgments:}

Thank you to all members of the field crews who participated in this project, including: F. Bennett, C. Carroll, T. Fitzgerald, T. Hann, M. Holder, C. Kennedy, A. Kingsley, K. Menchenton, J. Miner, A. Mullie, K. Nicol, D. Potter, and B. Rodriguez. T. Newbury ably managed the field program in 1999 and 2000. S. Flemming, S. Taylor, G. Kerri, the warden staff, and park interpreters provided invaluable help at Gros Morne National Park. Funding and support was provided by Parks Canada (GMNP), Western Newfoundland Model Forest, Corner Brook Pulp and Paper Limited, Government of Newfoundland and Labrador Department of Forest Resources and Agrifoods, Forestry and Wildlife Division-Pasadena, Environment Canada's Science Horizons Program, Environment Canada (ACWERN), and an NSERC Discovery Grant to PDT.

\section{LITERATURE CITED}

Bayne, E. M., and K. A. Hobson. 2001. Effects of habitat fragmentation on pairing success of ovenbirds: importance of male age and floater behavior. Auk 118:380-388.

Bélisle, M. 2005. Measuring landscape connectivity: the challenge of behavioral landscape ecology. Ecology 86:1988-1995.

Bélisle, M., A. Desrochers, and M.-J. Fortin. 2001. Influence of forest cover on the movements of forest birds: a homing experiment. Ecology 82:1893-1904.

Betts, M. G., G. J. Forbes, A. W. Diamond, and 
P. D. Taylor. In press. Independent effects of habitat amount and fragmentation on songbirds in a forest mosaic: an organism-based approach. Ecological Applications

Broström, G. A. 2003. Generalized linear models with random intercepts. Available online at: http://www.stat.umu.se/forskning/reports/glmmML. pdf.

Burnham, K.P., and D. R. Anderson. 2002. Model selection and multi-model inference: a practical information-theoretic approach. Springer, New York, New York, USA.

Collett, D. 1991. Modelling binary data. Chapman and Hall, London, UK.

Cumming, S. G., F. K. A. Schmiegelow, and P. J. Burton. 2000. Gap dynamics in boreal aspen stands: is the forest older than we think? Ecological Applications 10:744-759.

Drapeau, P., A. Leduc, J.-F. Giroux, J.-P. L. Savard, Y. Bergeron, and W. L. Vickery. 2000. Landscape-scale disturbances and changes in bird communities of boreal mixed-wood forests. Ecological Monographs 70:423-444.

Drolet, B., A. Desrochers, and M.-J. Fortin. 1999. Effects of landscape structure on nesting songbird distribution in a harvested boreal forest. Condor 101:699-704.

Dunning, J. B., B. J. Danielson, and H. R. Pulliam. 1992. Ecological processes that affect populations in complex landscapes. Oikos 65:169-175.

Erskine, A. J. 1977. Birds in boreal Canada: communities, densities, and adaptations. Canadian Wildlife Service Report Series Number 41, Ottawa, Ontario, Canada.

Fahrig, L. 2001. How much habitat is enough? Biological Conservation 100:65-74.

Flather, C. H., and M. Bevers. 2002. Patchy reaction-diffusion and population abundance: the relative importance of habitat amount and arrangement. American Naturalist 159:40-56.

Guénette, J.-S., and M.-A. Villard. 2005. Thresholds in forest bird response to habitat alteration as quantitative targets for conservation. Conservation Biology 19:1168-1180.

Gunn, J. S., A. Desrochers, M.-A. Villard, J. Bourque, and J. Ibarzabal. 2000. Playbacks of mobbing calls of Black-capped Chickadees as a method to estimate reproductive activity of forest birds. Journal of Field Ornithology 71:472-483.

Heikkinen, R. K., M. Luoto, R. Virkkala, and K. Rainio. 2004. Effects of habitat cover, landscape structure and spatial variables on the abundance of birds in an agricultural-forest mosaic. Journal of Applied Ecology 41:824-835.

Hosmer, D. W., and S. Lemeshow. 2000. Applied Logistic Regression. Second edition. John Wiley and Sons, New York, New York, USA.

Jonsen, I., and P. D. Taylor. 2000. Calopteryx damselfly dispersions arising from multi-scale responses to landscape structure. Conservation Ecology 4: 4. [online] URL:

http://www.consecol.org/vol4/iss2/art4.

Krawchuk, M. A., and P. D. Taylor. 2003. Changing importance of habitat structure across multiple spatial scales for three species of insects. Oikos 103:153-161.

Lambert, J. D., and S. J. Hannon. 2000. Shortterm effects of timber harvest on abundance, territory characteristics, and pairing success of Ovenbirds in riparian buffer strips. Auk 117:687-698.

Marshall, M. R., and R. J. Cooper. 2004. Territory size of a migratory songbird in response to caterpillar density and foliage structure. Ecology 85:432-445.

Mazerolle, M. J., and M.-A. Villard. 1999. Patch characteristics and landscape context as predictors of species presence and abundance: a review. Écoscience 6:117-124.

McCarthy, J. 2001. Gap dynamics of forest trees: a review with particular attention to boreal forests. Environmental Reviews 9:1-59.

McCarthy, J. W. T. 2004. Natural disturbance and structure in two primary boreal forests of western Newfoundland. Dissertation. University of British Columbia, Vancouver, British Columbia, Canada. 
Miller, J. R., M. D. Dixon, and M. G. Turner. 2004. Response of avian communities in large-river floodplains to environmental variation at multiple scales. Ecological Applications 14:1394-1410.

Norris, D. R., and B. J. M. Stutchbury. 2001. Extraterritorial movements of a forest songbird in a fragmented landscape. Conservation Biology 15:729-736.

Norton, M. R., S. J. Hannon, and F. K. A. Schmiegelow. 2000. Fragments are not islands: patch vs landscape perspectives on songbird presence and abundance in a harvested boreal forest. Ecography 23:209-223.

Pham, A. T., L. De Grandpré, S. Gauthier, and Y. Bergeron. 2004. Gap dynamics and replacement patterns in gaps of the northeastern boreal forest of Quebec. Canadian Journal of Forest Research 34:353-364.

Pinheiro, J. C., and D. M. Bates. 2000. Mixedeffects models in S and S-Plus. Springer, New York, New York, USA.

Ralph, C. J., G. R. Geupel, P. Pyle, T. E. Martin, and D. F. DeSante. 1993. Handbook of field methods for monitoring landbirds. General Technical Report PSW-GTR-144. U.S. Department of Agriculture Forest Service, Albany, California, USA.

Ricketts, T. H. 2001. The matrix matters: effective isolation in fragmented landscapes. American Naturalist 158:87-99.

Rowe, J. S. 1972. Forest regions of Canada. Canadian Forestry Service Publication Number 1300, Ottawa, Ontario, Canada.

Schmiegelow, F. K. A., C. S. Machtans, and S. J. Hannon. 1997. Are boreal birds resilient to forest fragmentation? An experimental study of shortterm community responses. Ecology 78:1914-1932.

Setterington, M. A., I. D. Thompson, and W. A. Montevecchi. 2000. Woodpecker abundance and habitat use in mature balsam fir forests in Newfoundland. Journal of Wildlife Management 64:335-345.

Skrondal, A., and S. Rabe-Hesketh. 2004.
Generalized latent variable modeling: multilevel, longitudinal and structural equation models. Chapman and Hall/CRC, Boca Raton, Florida, USA.

Stocks, B. J., J. A. Mason, J. B. Todd, E. M. Bosch, B. M. Wotton, B. D. Amiro, M. D. Flannigan, K. G. Hirsch, K. A. Logan, D. L. Martell, and W. R. Skinner. 2002. Large forest fires in Canada, 1959-1997. Journal of Geophysical Research 108 (D1) :8149, doi:10.1029/2001JD000484

Sturtevant, B. R., J. A. Bissonette, and J. N. Long. 1996. Temporal and spatial dynamics of boreal forest structure in western Newfoundland: silvicultural implications for marten habitat management. Forest Ecology and Management 87:13-25.

Taylor, P. D., L. Fahrig, K. Henein, and G. Merriam. 1993. Connectivity is a vital element of landscape structure. Oikos 68:571-573.

Thompson, I. D., H. A. Hogan, and W. A. Montevecchi. 1999. Avian communities of mature balsam fir forests in Newfoundland: agedependence and implications for timber harvesting. Condor 101:311-323.

Thompson, I. D., D. J. Larson, and W. A. Montevecchi. 2003. Characterization of old "wet boreal" forests, with an example from balsam fir forests of western Newfoundland. Environmental Reviews 11:S23-S46.

Trzcinski, M. K., L. Fahrig, and G. Merriam. 1999. Independent effects of forest cover and fragmentation on the distribution of forest breeding birds. Ecological Applications 9:586-593.

Vaida, F., and S. Blanchard. 2005. Conditional Akaike information for mixed-effects models. Biometrika 92:351-370.

Van Horne, B. 1983. Density as a misleading indicator of habitat quality. Journal of Wildlife Management 47:893-901.

Vega Rivera, J. H., J. H Rappole, W. J. McShea, and C. A. Haas.1998. Wood thrush postfledging movements and habitat use in northern Virginia. Condor 100:69-78.

Villard, M.-A., M. K. Trzcinski, and G. Merriam. 
1999. Fragmentation effects on forest birds: relative influence of woodland cover and configuration on landscape occupancy. Conservation Biology 13:774-783.

Walters, C. 1997. Challenges in adaptive management of riparian and coastal ecosystems. Conservation Ecology 1(2): 1. [online] URL:

http://www.consecol.org/vol1/iss2/art1/.

Walters, C. J. 1986. Adaptive management of renewable resources. McMillan, New York, New York, USA.

Warkentin, I. G., A. L. Fisher, S. P. Flemming, and S. E. Roberts. 2003. Response to clear-cut logging by northern waterthrushes. Canadian Journal of Forest Research 33:755-762.

Whitaker, D. M., and W. A. Montevecchi. 1997. Breeding bird assemblages associated with riparian, interior forest, and nonriparian edge habitats in a balsam fir ecosystem. Canadian Journal of Forest Research 27:1159-1167. 